\title{
Energy balance of five fodder cropping systems in the irrigated lowlands of Northern Italy
}

\author{
Cesare Tomasoni, ${ }^{1}$ Lamberto Borrelli, ${ }^{1}$ Massimo Brambilla ${ }^{2}$ \\ ${ }^{1}$ CRA-FLC Centro di Ricerca per le Produzioni Foraggere e Lattiero Casearie, Lodi; ${ }^{2}$ Dipartimento \\ VSA, Facoltà di Medicina Veterinaria, Università Statale di Milano, Italy
}

\begin{abstract}
Extensification has recently become an important option in Western European agriculture, driven both by economic considerations (product surpluses together with the fact that developed countries cropping systems have been heavily relying on fossil energy) and growing public concern on the possible adverse effects of intensive farming on the environment and human health. The adoption of rational fodder crop rotations, with the rediscovery of the beneficial effect of the meadow, is viewed as a possible mean to reduce the impact of farming systems in the lowlands of northern Italy, characterised by highly intensive cropping and animal husbandry. For this reason our study examines the effects of crop rotation on the energy balance during 1985-2007 period in a long-term crop rotation trial in Northern Italy comparing five fodder crop systems, different in the degree of crop intensification and for the presence or absence of the meadow: a 1-year continuous cereal double cropping (R1); a 3-year rotation (R3); a 6-year rotation (R6); a permanent meadow (PM); and a continuous grain maize cropping (CM). Each rotation was subjected to two input treatments, defined as high (mostly used in lowlands of northern Italy) and low (input reduction of ca. 30\%) respectively, in terms of nutrient levels, herbicide doses, and soil tillage methods. The crop rotations exerted a marked influence on the energy balance. The most efficient rotations in terms of net energy production energy efficiency have been characterized by reduced length and presence of maize and catch-crops.
\end{abstract}

Correspondence: Cesare Tomasoni, Centro di Ricerca per le Produzioni Foraggere e Lattiero Casearie, viale Piacenza 29, 26900 Lodi, Italy. Tel. +39.0371 .404733 - Fax: +39.0371 .31853 .

E-mail: cesare.tomasoni@entecra.it

Key words: crop rotation, fodder crop, meadow, northern Italy, energy balance.

Acknowledgements: the authors would like to thank Mr. Angelo Passerini and Mr. Paolo Broglia for their contribution in the experimental work.

Received for publication: 8 October 2010.

Accepted for publication: 27 December 2010.

(C) Copyright C. Tomasoni et al., 2011

Licensee PAGEPress, Italy

Italian Journal of Agronomy 2011; 6:e9

doi:10.4081/ija.2011.e9

This article is distributed under the terms of the Creative Commons Attribution Noncommercial License (by-nc 3.0) which permits any noncommercial use, distribution, and reproduction in any medium, provided the original author(s) and source are credited.

\section{Introduction}

The outstanding technological progress occurred in the second half of the last century in various fields (e.g. chemistry, mechanics, genetics, etc.) and the actions taken by the E.U. Common Agricultural Policy, were the causes of the agriculture extreme intensification which occurred in the regions with favourable pedo-climatic conditions. A dramatic increase was subsequently induced in the yields of all the crops as well as the simplification, and the consequent specialisation, of farming systems (Parente, 1996). In particular, during the last decades Western European countries experienced some crucial changes to reduce the impact of cropping on soil pollution. On one hand, the surpluses of many agricultural products causing stagnation of prices, and, on the other, the growing concern of public opinion about the possible side effects of intensive farming on environment and human health, because of the massive recourse to potentially pollutant factors, led the Common Agricultural Policy to pursue the goal of agricultural extensification (Smith and Olesen, 2010; Postma-Blaauw et al., 2010; Cruse et al., 2010).

Therefore, sustainable farming systems based on cropping and/or animal husbandry requiring lower amounts of non-renewable inputs have been increasingly encouraged and, accordingly, financially supported (Parente, 1996; Castoldi and Bechini, 2010).

In the last 40 years, the lowland area of the Po Valley in northern Italy experienced a process of outstanding cropping intensification and simplification together with the related livestock systems so that, nowadays, they are almost exclusively based on continuous cereal cropping (autumn-sown Italian ryegrass, Lolium multiflorum Lam., followed by spring-sown maize, Zea mais L., both used for silage), and on the rearing, under confinement, of Holstein dairy cows with high genetic and productive standards. This process caused a drastic reduction of permanent and rotational meadows, which despite representing the main forage resource before the 1960, have decreased of about $50 \%$ in land area since then (Giardini and Ziliotto, 1988). The overweening capital input and the large availability of production factors not belonging to the farm allowed carrying out such an extensive agriculture whose products were transformed into milk both for human consumption and dairy industry.

Energy analysis as indicator of farming system sustainability was developed during the 70's as consequence of the oil crisis (Bonari et al., 1992; Giardini et al., 1983; Pimentel, 1993). Energy analyses of norenewable source use is preferable when the reduction of the used energy has pursued in the agricultural systems. Up to now many authors focused their work on energy balance of both conventional and low energy input cropping systems considering both food and biomass crops (Sharma et al., 2011; Arvidsson, 2010; Deike et al., 2008; Gelfand et al., 2010; Boehmel et al., 2008; Rathke et al., 2007; Rathke and Diepenbrock, 2006; Monti and Venturi, 2003; Hülsbergen et al., 2001) and with reference to external energy inputs (Cruse et al., 2010; Wiens 
et al., 2008); nevertheless, an in depth study considering the presence of meadow in the cropping system is still missing.

In this paper we compare the productivity and energy balance of five forage crop systems which represent different models of forage production in Lombardy plain where low input farming systems are expected to be preferred to the current widespread high input farming systems using large amounts of agrochemicals and machinery: the present paper reports the results gathered in 22 years after the trial's establishment.

\section{Materials and Methods}

The experiment was carried out in Lodi, Italy ( $45^{\circ} 19^{\prime} \mathrm{N}, 9^{\circ} 30^{\prime} \mathrm{E}, 81$ $\mathrm{m}$ asl), which is a location representative of the alluvial Po Valley. The used soil was a sandy-loam one of the mollic Hapludalf family, with sub acid pH (6.2), low in nitrogen, organic matter, and exchangeable potassium, and with good provision of assimilable phosphorus. The climate is typical of the lowlands of northwestern Italy: the average annual rainfall is about $800 \mathrm{~mm}$ (well distributed along the year) and the average annual daily temperature is $12.5^{\circ} \mathrm{C}$ with a minimum of $1.1^{\circ} \mathrm{C}$ in January and a maximum of $22.9^{\circ} \mathrm{C}$ in July.

Five cropping systems have been included in this investigation since 1984: i) one annually-repeated double crop (coded as R1) of autumnsown Italian ryegrass + spring-sown maize both used for silage; ii) a three-year rotation (coded as R3) made of autumn-sown barley (Hordeum vulgare L.) + spring-sown maize both for silage purpose; Italian ryegrass + maize (both for silage)/grain maize; iii) a six-year rotation (R6): 3 years of Italian ryegrass + maize (both for silage) / 3 years of meadow (Ladino white clover, Trifolium repens $\mathrm{L} .,+$ tall fescue, Festuca arundinacea Schreb.) for hay making; iv) a continuous grain maize cropping (CM); and v) a permanent meadow (PM) (Table 1). Each rotation underwent two kind of treatments corresponding to an high input level $(\mathrm{H}$, mostly used in northern Italy lowlands) and low input level (L). The difference among these was "L" one was made of about $70 \%$ of the organic, chemical fertilisation and herbicide amounts given with the $H$ one (Onofrii et al., 1993, 1996).

A further difference between $\mathrm{H}$ and $\mathrm{L}$ treatments concerned soil tillage before autumn-sown crops. In the $H$ treatment, soil was ploughed to a depth of $30 \mathrm{~cm}$ and then rotary-cultivated, while in the $L$ one it was rotary-cultivated to a depth of $15 \mathrm{~cm}$ only. In both treatments all maize crops, either for silage or grain production, were ploughed before sowing, and rotary-cultivated along the rows after plant emergence also to enhance the covering of the nitrogen fertiliser applied at post-emergence stage (half of total required amount). Every year, in both the treatments, four border irrigations of about $1000 \mathrm{~m}^{3} \mathrm{ha}^{-1}$ each were provided to the whole trial; for the sowing period and all the other cultural practices we referred to those typical for each considered crop in the region.

The experimental design on annual basis was a strip-plot with three replications in as many blocks; the main plots being represented by the input level and the sub-plots by the compared rotations. All the phases (crops) contemplated by the rotations, as indicated in Table 1, were present at the same time in each year, in each combination of block and input level, to avoid possible confounding effects of the factor year when comparing rotations made up of different phases in different years. In the experimental layout, two crops present in the same year in one rotation (e.g. Italian ryegrass and maize) were considered as just one crop. Altogether the trial included 72 plots (12 crop-phases $\times 3$ blocks $\times 2$ input levels), each measuring $60 \mathrm{~m}^{2}(6 \times 10 \mathrm{~m})$.

The different cropping systems have been compared according to the energy balance sheet, using the gross energy method to deter- mine the energy inputs of the cropping systems. This method takes into account only fossil energy sources without considering both renewable sources and human labour (Ceccon et al., 2002). It calculates the fossil energy directly used in crop production (e.g. oil, lubricants) as well as the energy embedded in agricultural requisites (e.g. machinery, seeds, agrochemicals, etc.). To this purpose, basic data on agricultural requisite use were regularly recorded from 1985 to 2006 taking into account the type of used machinery and its working times, the mass of applied fertilisers and agrochemicals, the seed rates and the irrigation depths. Table 2 summarises the energy conversion rates for agricultural requisites (Pimentel, 1980; Pellizzi, 1992, Jarach, 1985). Energy for machine depreciation was estimated combining mass conversion rate, reliable life and finding machinery val-

Table 1. List and sequence of the twelve crops in the five crop rotations under comparison.

\begin{tabular}{|c|c|c|c|c|}
\hline $\begin{array}{l}\text { Six-year } \\
\text { rotation } \\
\text { (R6) }\end{array}$ & $\begin{array}{l}\text { Three-year } \\
\text { rotation } \\
\text { (R3) }\end{array}$ & $\begin{array}{l}\text { Annual } \\
\text { rotation } \\
\text { (continuous } \\
\text { double } \\
\text { cropping) } \\
\text { (R1) }\end{array}$ & $\begin{array}{l}\text { Continuous } \\
\text { grain } \\
\text { maize } \\
\text { cropping } \\
\text { (CM) }\end{array}$ & $\begin{array}{l}\text { Permanent } \\
\text { meadow } \\
\text { (PM) }\end{array}$ \\
\hline IR-SM & SB-SM & IR-SM & GM & PM \\
\hline IR-SM 2 & IR-SM & & & \\
\hline $\mathrm{IR}-\mathrm{SM}_{3}$ & $\mathrm{GM}$ & & & \\
\hline \multicolumn{5}{|l|}{$\mathrm{RM}_{1}$} \\
\hline \multicolumn{5}{|l|}{$\mathrm{RM}_{2}$} \\
\hline $\mathrm{RM}_{3}$ & & & & \\
\hline
\end{tabular}

IR-SM, Italian ryegrass + maize (both for silage); RM, rotational meadow; SB-SM, barley + maize (both for silage); GM, grain maize.

Table 2. Energy (MJ=mega Joule) conversion rates for agricultural equisites/commodities.

\begin{tabular}{|c|c|c|c|c|}
\hline Category & $\begin{array}{l}\text { Agricultural } \\
\text { practice/requisite }\end{array}$ & $\begin{array}{l}\text { Size } \\
\text { unit }\end{array}$ & Value & Reference \\
\hline $\begin{array}{l}\text { Machine } \\
\text { (Depreciation }=\mathrm{M} \times\end{array}$ & $\begin{array}{l}\text { Agricultural practices } \\
\times C R \times V / R L \times W T)\end{array}$ & $\mathrm{MJ} \times \mathrm{Hp} \times \mathrm{h}^{-1}$ & 7.68 & $\begin{array}{c}\text { Pimentel } \\
1980\end{array}$ \\
\hline \multirow[t]{2}{*}{ Contents } & Tractors and combines & $\mathrm{MJ} \mathrm{kg-1}$ & 92.00 & $\begin{array}{c}\text { Pimentel } \\
1980\end{array}$ \\
\hline & Other equipment & $\mathrm{MJ} \mathrm{kg}^{-1}$ & 69.00 & $\begin{array}{c}\text { Pimentel } \\
1980\end{array}$ \\
\hline \multirow[t]{3}{*}{ Fertiliser } & Nitrogen & $\mathrm{MJ} \mathrm{kg}^{-1}$ & 62.00 & $\begin{array}{l}\text { Pimentel } \\
1980\end{array}$ \\
\hline & Phosphorous & $\mathrm{MJ} \mathrm{kg}^{-1}$ & 13.65 & $\begin{array}{l}\text { Pimentel } \\
1980\end{array}$ \\
\hline & Potassium & $\mathrm{MJ} \mathrm{kg}^{-1}$ & 7.68 & $\begin{array}{l}\text { Pimentel } \\
1980\end{array}$ \\
\hline Seeds & & $\mathrm{MJ} \mathrm{kg}^{-1}$ & 15.00 & $\begin{array}{c}\text { Pimentel } \\
1980\end{array}$ \\
\hline \multirow[t]{3}{*}{ Agrochemicals } & Herbicides & MJ kg-1 & 189.00 & $\begin{array}{l}\text { Pimentel } \\
1980\end{array}$ \\
\hline & Geo-insecticides & $\mathrm{MJ} \mathrm{kg}^{-1}$ & 67.00 & $\begin{array}{l}\text { Pimentel } \\
1980\end{array}$ \\
\hline & Plastic material & $\mathrm{MJ} \mathrm{kg}^{-1}$ & 100.80 & $\begin{array}{l}\text { Pimentel } \\
1980\end{array}$ \\
\hline MFU & & MJ & 7.24 & $\begin{array}{c}\text { Chase } \\
1981\end{array}$ \\
\hline
\end{tabular}

$\mathrm{M}$, mass of the machine; $\mathrm{CR}$, conversion rate; $\mathrm{V}$, unit value (dimensionless) at the end of the reliable life; RL, reliable life; WT, working time; MFU, milk feed unit. 
ues and working times. Fuel consumption of machinery was set at 180 gr $\mathrm{Hp}^{-1} \mathrm{~h}^{-1}$. The output energy content of the produced forage has been estimated with NIRS method (Chase, 1981) as net energy for milk cow production (Milk Feed Units=MFU=7.24 MJ).

The results were subjected to analysis of variance (ANOVA) performed with the SAS software.

\section{Results and Discussion}

Table 3 reports the milk feed units yield in the different crop systems at two different intensification levels over the twenty-two year period of the trial: on average, short rotation and level low of intensification (L) showed large yield oscillation among the years, as indicated by high values of the coefficient of variation (CV\%) as compared to the other rotations.

On average, the higher yield stability was achieved in the $\mathrm{R} 6$ rotation while, on the contrary, PM and CM rotations at input L showed large yield oscillations as indicated CV values higher than $20 \%$. This suggests that in the R6 treatment it occurs the establishment of satisfactory agricultural practices for these crop systems. Differences among mean values of milk feed units from each cropping systems are very high, ranging from 22,477 and 20,281 MFU ha-1 $\mathrm{yr}^{-1}$ (for R1, at $\mathrm{H}$ and $\mathrm{L}$ input levels) to 8587 and 7210 (for PM). At both input levels each rotation productivity is significantly different from the others according to the following rank: $\mathrm{R} 1>\mathrm{R} 3>\mathrm{R} 6>\mathrm{CM}>\mathrm{PM}$.

Table 4 depicts the overall energy use for crop growth (MJ ha ${ }^{-1}$ year $^{-1}$ ) in the 22 -years trial under different crop systems by grouping homogeneous agricultural practices into four categories (machinery, irrigation, seed and agrochemicals included fertilisers) while cumulated values and share of the total energy use for single rotation are reported in Table 5. It comes out that great part of machinery energy (more than 50\%) was spent for harvesting in the meadow (mowing, as well as hay raking, conditioning, baling and transporting) while in other crop systems the highest energy requirements were those for maize tillage and fertilisation. The maximum energy requirement (machinery, irrigation, seed and agrochemicals) is the one of maize grown in the R3 trial both at $\mathrm{H}$ and $\mathrm{L}$ energy level with 44,986 and $38,439 \mathrm{MJ} \mathrm{ha}^{-1}$ year $^{-1}$ respectively and with an incidence percentage of machinery ranging from $49.8 \%$ to $56.1 \%$. Italian ryegrass and silage barley are the crops requiring the lowest energy (about 26,000 MJ $\mathrm{ha}^{-1}$ year $^{-1}$ ) while silage maize requires 39,789 and $33,641 \mathrm{MJ}^{\mathrm{h}} \mathrm{a}^{-1}$

Table 3. Milk feed units yields $\left(\mathrm{ha}^{-1} \mathrm{yr}^{-1}\right)$ in different cropping systems and coefficient of variation overall 22 years of the trial.

\begin{tabular}{|c|c|c|c|c|c|}
\hline \multirow[t]{2}{*}{ Rotation } & \multicolumn{2}{|c|}{ Treatment $\mathrm{H}$} & \multicolumn{2}{|c|}{ Treatment L } & \multirow[t]{2}{*}{ Significance } \\
\hline & MFU & CV (\%) & MFU & CV (\%) & \\
\hline R1 & $22,477^{\mathrm{a}}$ & 14.8 & $20,281^{\mathrm{a}}$ & 17.7 & $* *$ \\
\hline $\mathrm{CM}$ & $11,921^{\mathrm{d}}$ & 16.5 & $9932^{\mathrm{d}}$ & 25.1 & $* * *$ \\
\hline PM & $8587^{\mathrm{e}}$ & 21.2 & $7210^{\mathrm{e}}$ & 23.2 & $* * *$ \\
\hline R6 & $15,842^{c}$ & 12.8 & $14,234^{c}$ & 13.6 & $* * *$ \\
\hline R3 & $18,826^{\mathrm{b}}$ & 13.8 & $16,342^{\mathrm{b}}$ & 14.3 & $* * *$ \\
\hline
\end{tabular}

MFU, milk feed unit; a-e means followed by same letter are not different for Duncan's test at $\mathrm{P}<0.01 ;{ }^{*} \mathrm{P}<0.01 ;{ }^{* * *} \mathrm{P}<0.001$; CV, coefficient of variation overall years (1985-2006).

Table 4. Energy content of agricultural practices/requisites $\left(\mathrm{MJ} \mathrm{ha}^{-1} \mathrm{year}^{-1}\right)$ for different crops and inputs treatment in the compared rotations.

\begin{tabular}{|c|c|c|c|c|c|c|c|c|c|c|c|c|c|c|c|c|c|c|c|}
\hline \multirow[t]{3}{*}{ Category } & \multirow{3}{*}{$\begin{array}{l}\text { Agricultural } \\
\text { practice/requisite }\end{array}$} & \multirow{2}{*}{\multicolumn{2}{|c|}{ PM }} & \multirow{2}{*}{\multicolumn{2}{|c|}{$\begin{array}{l}\text { Meadow } \\
1^{\text {st }} \text { year }\end{array}$}} & \multirow{2}{*}{\multicolumn{2}{|c|}{$\begin{array}{l}2^{\text {nd }} \text { and } \\
3^{\text {rd }} \text { year }\end{array}$}} & \multirow{2}{*}{\multicolumn{2}{|c|}{$\begin{array}{c}\text { Italian ryegrass } \\
\text { R1-R3-R6 }\end{array}$}} & \multicolumn{4}{|c|}{ Grain maize } & \multicolumn{4}{|c|}{ Silage maize (R1-R3-R6) } & \multirow{2}{*}{\multicolumn{2}{|c|}{$\begin{array}{c}\text { Silage barley } \\
\text { R3 }\end{array}$}} \\
\hline & & & & & & & & & & \multicolumn{2}{|c|}{$\mathrm{CM}$} & \multicolumn{2}{|c|}{ R3 } & \multicolumn{2}{|c|}{$\begin{array}{c}\text { After I. } \\
\text { ryegrass }\end{array}$} & \multicolumn{2}{|c|}{$\begin{array}{c}\text { After } \\
\text { barley }\end{array}$} & & \\
\hline & & H & L & H & L & $\mathrm{H}$ & L & H & L & H & L & H & L & $\mathrm{H}$ & L & $\mathrm{H}$ & L & H & L \\
\hline \multirow[t]{12}{*}{ Machinery } & Chopping/harwesting rapier & 0 & 0 & 0 & 0 & 0 & 0 & 0 & 0 & 807 & 807 & 3226 & 3226 & 0 & 0 & 0 & 0 & 0 & 0 \\
\hline & Plough & 0 & 0 & 2489 & 2489 & 0 & 0 & 2489 & 1382 & 2489 & 2489 & 2489 & 2489 & 2489 & 2489 & 2489 & 2489 & 2489 & 1382 \\
\hline & Clod br & 0 & 0 & 2305 & 2305 & 0 & 0 & 2305 & 1383 & 2305 & 2305 & 2305 & 2305 & 2305 & 2305 & 2305 & 2305 & 2305 & 2305 \\
\hline & Row we & 0 & 0 & 0 & 0 & 0 & 0 & 0 & 0 & 768 & 768 & 768 & 768 & 768 & 768 & 768 & 768 & 0 & 0 \\
\hline & Roll & 0 & 0 & 384 & 384 & 0 & 0 & 384 & 384 & & 384 & & 384 & 384 & & 384 & 384 & 38 & 384 \\
\hline & Ferti & 883 & 883 & 883 & 883 & 883 & 883 & 845 & 845 & 461 & 461 & 461 & 461 & 461 & 461 & 461 & 461 & 845 & 845 \\
\hline & Manure & 2689 & 2258 & 2689 & 2258 & 0 & 0 & 0 & 0 & 0 & 0 & 0 & 0 & 2689 & 2258 & 2689 & 2358 & 0 & 0 \\
\hline & Sowing & 0 & 0 & 576 & 576 & 0 & 0 & 576 & 576 & 499 & 499 & 499 & 499 & 499 & 499 & 499 & 499 & 576 & 576 \\
\hline & Spray. & 0 & 0 & 0 & 0 & 0 & 0 & 0 & 0 & 307 & 307 & 307 & 307 & 307 & 307 & 307 & 307 & 307 & 307 \\
\hline & Mowi & 2689 & 2689 & 2151 & 2151 & 2689 & 2689 & 0 & 0 & 0 & 0 & 0 & 0 & 0 & 0 & 0 & 0 & 0 & 0 \\
\hline & $\mathrm{H}$ & 11.54 & 11.354 & 8681 & 8681 & 11.54 & 1.14 & 4610 & 4610 & 3572 & 3572 & 3572 & 3572 & 5070 & 5070 & 4563 & 4563 & 4424 & 4424 \\
\hline & Drying & 0 & 0 & 0 & 0 & 0 & 0 & 0 & 0 & 6828 & 5989 & 6828 & 5989 & 0 & 0 & 0 & 0 & 0 & 0 \\
\hline \multicolumn{2}{|c|}{ Machine depreciation } & 2500 & & 3390 & 3287 & 2290 & 2200 & 2189 & 2086 & 1565 & 1565 & 1565 & 1565 & 2235 & 2235 & 2235 & 2235 & 2089 & 1886 \\
\hline & Subtotal & 8772.54 & 8241.354 & 23,548 & 23,014 & 5873.54 & 5773.14 & 13,398 & 11,266 & 19,985 & 19,146 & 22,404 & 21,565 & 17,207 & 16,776 & 16,7 & 16,369 & 13,419 & 12,109 \\
\hline \multicolumn{2}{|l|}{ Irrigation } & 2151 & 2151 & 2420 & 2420 & 2151 & 2151 & 0 & 0 & 2823 & 2823 & 2823 & 2823 & 2823 & 2823 & 2420 & 2420 & 0 & 0 \\
\hline \multicolumn{2}{|l|}{ Seed } & 0 & 0 & 600 & 600 & 0 & 0 & 750 & 750 & 700 & 700 & 700 & 700 & 700 & 700 & 300 & 300 & 313 & 3136 \\
\hline \multicolumn{20}{|c|}{ Agrochemicals } \\
\hline & Fertiliser & 10.714 & 7469 & 10.714 & 7469 & 10.714 & 7469 & 11,583 & 8108 & 17,633 & 12,344 & 17,633 & 12,344 & 17,633 & 12,344 & 17,633 & 12,344 & 9527 & 6809 \\
\hline & Herbicides & 0 & 0 & 0 & 0 & 0 & 0 & 0 & 0 & 756 & 529 & 756 & 529 & 756 & 529 & 756 & 529 & 240 & 160 \\
\hline & Geo-in & 0 & 0 & 0 & 0 & 0 & 0 & 0 & 0 & 670 & 469 & 670 & 469 & 670 & 469 & 670 & 469 & 0 & 0 \\
\hline & Plastic & 2863 & 2419 & 564 & 564 & 2872 & 2419 & 0 & 0 & 0 & 0 & 0 & 0 & 0 & 0 & 0 & 0 & 0 & 0 \\
\hline & Subtotal & 2873.714 & 9888 & 574.714 & 8033 & 2882.714 & 19888 & 11,583 & 8108 & 19,059 & 13,342 & 19,059 & 13,342 & 19,059 & 13,342 & 19,059 & 13,342 & 9767 & 6969 \\
\hline
\end{tabular}

PM, permanent meadow; R1, 1-year continuous cereal double cropping; R3, 3-year rotation; R6, 6-year rotation; CM, continuous grain maize cropping; 
Table 5. Energy content of agricultural practices/requisites $\left(\mathrm{MJ} \mathrm{ha}^{-1}\right.$ year $\left.^{-1}\right)$ groupped in 4 principal categories for different crops and input treatments in the compared farming systems and share of energy content $(\%)$.

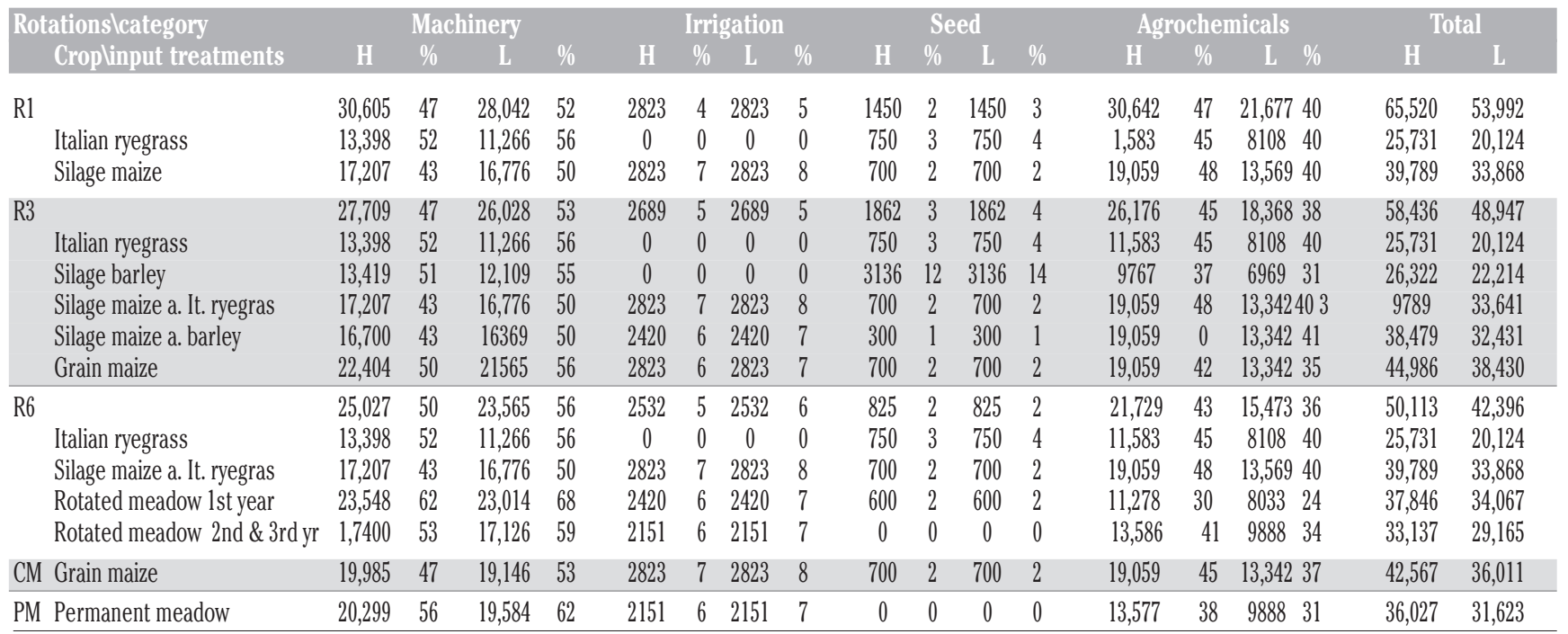

R1, 1-year continuous cereal double cropping; R3, 3-year rotation; R6, 6-year rotation.

year-1 for treatment $\mathrm{H}$ and $\mathrm{L}$ respectively spending great part of energy for agrochemicals.

In all the studied rotational farming systems, energy required for fertilization and agrochemicals was on average the most relevant item whose cost of use exceeded the harvesting one in all the rotations at $\mathrm{H}$ input level with exception for the permanent meadow. With reference to the $\mathrm{L}$ input level, the most important energy input reduction is ascribable to the fertilization amount.

Table 6 summarises the main variables of the input/output balance sheet. On average, during the 22 years trial, rotations across input treatments produced different amounts of estimated energy for milk production: R1 showed the highest energy output with 162,733 MJ $\mathrm{ha}^{-1}$ year $^{-1}$ (19\% more than R3, $42 \%$ more than R6, $88 \%$ more than $\mathrm{CM}$ and $260 \%$ more than PM). This farming system output mainly depends on single crop output, with silage maize producing the highest amount of energy if compared to the other crops.

At low intensification level (L) inputs energy ranges from 53,992 (R1) to $31,623 \mathrm{MJ} \mathrm{ha}^{-1}$ year-1 (PM): the lack of meadow causes R1 and R3 to have the higher values of inputs. At high treatment level (H) there is an appreciable increase of energy required by rotations whose the mean values range from 65,520 (R1) to $36,027 \mathrm{MJ}^{\mathrm{h}}{ }^{-1}$ year $^{-1}(\mathrm{PM})$. On average, the amount of energy required by rotations was different for each input treatment level. The effect of rotations and input treatment on net energy is shown in Table 7. Here it can be pointed out how the net energy (energy output - energy input) was substantially different between rotations at the same level of input treatment, while comparing the two intensification levels at varying of the rotation shows that no difference in net energy can be seen for R1 and R6.

Therefore, net energy output from R1 is more than the triple than the one from PM. Mean outputs are lower for rotations including the meadow (R6 and PM), if compared with rotations without meadow (R1 and R3). In the same table, it can be noticed that also maize monoculture (CM) has a relatively low net energy but this can be ascribed to the fact that only grain has been transformed into energy for cow milk production.

Net/input energy ratios (or net energy production efficiency) are shown in the right part of the same table: here R1 is shown to be the most efficient cropping system in both $\mathrm{H}$ and $\mathrm{L}$ treatment, followed by R3 and R6 which do not show any significant difference between them, while the least efficient are CM an PM. These cropping systems
Table 6. Energy input and output (MJ ha $\left.\mathrm{hear}^{-1}\right)$ for different rotations.

\begin{tabular}{|c|c|c|c|c|}
\hline \multirow{2}{*}{$\begin{array}{l}\text { Rotation/input } \\
\text { treatment }\end{array}$} & \multicolumn{2}{|c|}{ Energy output } & \multicolumn{2}{|c|}{ Energy input } \\
\hline & $\mathrm{H}$ & $\begin{array}{c}\text { L } \\
\text { (MJ ha }\end{array}$ & $\begin{array}{c}\mathrm{H} \\
\left.\operatorname{ar}^{-1}\right)\end{array}$ & L \\
\hline R1 & 162,733 & 146,834 & 65,520 & 53,992 \\
\hline R3 & 136,300 & 118,316 & 58,436 & 48,947 \\
\hline $\mathrm{R} 6$ & 114,696 & 103,054 & 50,113 & 42,396 \\
\hline $\mathrm{CM}$ & 86,308 & 71,908 & 42,567 & 36,011 \\
\hline PM & 62,170 & 52,200 & 36,027 & 31,623 \\
\hline
\end{tabular}

Table 7. Net Energy (MJ ha ${ }^{-1}$ year $\left.^{-1}\right)$ and energy efficiency for different rotations.

\begin{tabular}{|c|c|c|c|c|}
\hline \multirow{2}{*}{$\begin{array}{l}\text { Rotation/input } \\
\text { treatment }\end{array}$} & \multicolumn{2}{|c|}{ Net energy $^{\circ}$} & \multicolumn{2}{|c|}{ Energy efficiency ${ }^{\circ}$} \\
\hline & H & $\begin{array}{c}\text { L } \\
\text { (MJ ha }\end{array}$ & $\begin{array}{c}\mathrm{H} \\
\left.\operatorname{tar}^{-1}\right)\end{array}$ & L \\
\hline R1 & $97,213^{\mathrm{aA}}$ & $92,842^{2 \mathrm{~A}}$ & $1.48^{\mathrm{aB}}$ & $1.72^{\mathrm{aA}}$ \\
\hline R3 & $77,864^{\mathrm{bA}}$ & $69,36 \mathrm{gbB}^{\mathrm{bB}}$ & $1.33^{\mathrm{bB}}$ & $1.42^{\mathrm{bA}}$ \\
\hline R6 & $64,583^{\mathrm{cA}}$ & $60,658^{\mathrm{bA}}$ & $1.29^{\mathrm{bB}}$ & $1.43^{\mathrm{bA}}$ \\
\hline $\mathrm{CM}$ & $43,74^{\mathrm{dA}}$ & $35,897 \mathrm{cB}$ & $1.03^{\mathrm{cA}}$ & $1.00^{\mathrm{cA}}$ \\
\hline PM & $26,143^{\mathrm{eA}}$ & $20,577^{\mathrm{dB}}$ & $0.73^{\mathrm{dA}}$ & $0.65^{\mathrm{dA}}$ \\
\hline
\end{tabular}

${ }^{\circ}$ Means followed by same letter are not different for Duncan's test at $\mathrm{P}<0.05$; ${ }^{\mathrm{a}-\mathrm{d}} \mathrm{valid}$ between the rotations; ${ }^{\mathrm{A}, \mathrm{B}_{\mathrm{valid}}}$ between the levels of intensification $\mathrm{H}$.

can therefore ranked as follows: $\mathrm{R} 1>\mathrm{R} 3=\mathrm{R} 6>\mathrm{CM}>\mathrm{PM}$.

The results of the comparison between the two input treatment levels within the same rotation (Table 7) shows that R1, R3 and R6 are more efficient when the inputs are reduced because they show an higher out/in ratio under low (L) input treatment level.

Another consideration that can be done is that, according to the discussed results and under the pedological, climatic and agricultural conditions occurring during the trial, the most efficient rotations turned out to have the following features: i) shortness; ii) including maize; iii) including catch crops (e.g. Italian ryegrass - silage maize or silage barley).

Limiting factors to crop productivity (e.g. water, light and nitrogen) 
are better used if rotations are more efficient: as a matter of fact, maize, belonging to $\mathrm{C} 4$ species, having a more efficient light use subsequently requires and uses higher amounts of water and nutrients. On the contrary, mixed cropping systems (meaning a main crop and followed by one catch crop within the same year: R1, R3 and R6 rotations) allow a better use of water and nutrients because of their prolonged soil coverage. On the contrary permanent meadow, despite having very high soil coverage, shows a low energy efficiency that can be due to its characteristic low yield potential. In case of low input level, the increase of the efficiency shown by R1, R3 and R6 rotations suggest that, to limit consumption of not renewable resources and environmental pollution by intensive agriculture, the chance of energy input reduction for these cropping systems should be seriously taken into account.

\section{Conclusions}

The data discussed in this paper can be considered representative of farming systems in the area of evaluation in as results of long-term experiments and some conclusions can be made.

- Energy analysis provides important information on fodder cropping systems properties.

- The overall productivity of the cropping systems was affected by the level of intensification and by the productivity of single crops especially maize.

- Farming systems mainly using external inputs seemed to induce higher crop yield stability than the more self-sufficient farming systems.

- Both net energy and energy efficiency evaluated on a cropping systems basis emphasise big differences among the compared types of agriculture and it seems that energy efficiency is mainly related to system outputs.

A final consideration suggested by our results concerns the level of intensiveness commonly applied to cropping systems in the region of evaluation. The fact that a $25-30 \%$ reduction of inputs, above all agrochemicals and fertilisers, involves a decrement of production less than proportional to the reduction of inputs and in the case of the net energy a no significant decrement in R1 and R6 should drive farmers to consider the chance of adopting less intensive agronomic practices, obtaining in exchange an increase of sustainability both under the economic and the environmental point of view.

\section{References}

Arvidsson J., 2010. Energy use efficiency in different tillage systems for winter wheat on a clay and silt loam in Sweden. Eur. J. Agron. 33.250256.

Boehmel C., Lewandowski I., Claupein W., 2008. Comparing annual and perennial energy cropping systems with different management intensities. Agr. Syst. 96:224-236.

Bonari E., Mazzoncini M., Peruzzi A., Silvestri N., 1992. Valutazioni energetiche di sistemi produttivi a diverso livello di intensificazione colturale. Inform. Agr. 1:11-25.

Castoldi N., Bechini, L., 2010. Energy, Nutrient and Economic Cross Indicators of Cropping Systems in Northern Italy. Ital. J. Agron. 5:1926.

Ceccon P., Coiutti C., Giovanardi R., 2002. Energy balance of four farming systems in north-eastern Italy. Ital. J. Agron. 6:73-84.

Chase L.E., 1981. Energy prediction equations in USA at NY Hydhia
Forage Laboratory. Production Agricultural Training School, Ithaca, NY, USA.

Cruse M.J., Liebmann M., Raman D.R., Wiedenhoeft M.H., 2010. Fossil Energy Use in Conventional and Low-External-Input Cropping Systems. Agron. J. 102: 934-941.

Deike S., Pallutt B., Melander B., Strassenmeyer J., Christen 0., 2008) Long-term productivity and environmental effects of arable farming as affected by crop rotation, soil tillage intensity and strategy of pesticide use: A case-study of two long-term field experiments in Germany and Denmark. Eur. J. Agron. 29:191-199.

Gelfand I., Snapp S.S., Robertson G.P., 2010. Energy Efficiency of Conventional, Organic, and Alternative Cropping Systems for Food and Fuel at a Site in the U.S. Midwest. Environ. Sci. Technol. 44:4006-4011.

Giardini L., Giovanardi R., Mosca G., 1983. Studio del bilancio energetico in quattro rotazioni colturali eseguite per un decennio con diversi livelli di concimazione e di irrigazione. Nota I: energia della sostanza secca prodotta e del prodotto agrario utile. Riv. Agron. 17:261-278.

Giardini L., Ziliotto U., 1988. Foraggicoltura e ambiente nella pianura padana. In: Il Futuro della Foraggicoltura Prativa nella Pianura Padana, ISCF, Lodi, Italy, pp 245-262.

Hülsbergen K.J., Feil B., Biermann S., Rathke G.W., Kalk W.D., Diepenbrock W., 2001. A method of energy balancing in crop production and its application in long-term fertilizer trial. Agr. Ecosyst. Environ. 86:303-321.

Jarach M., 1985. Sui valori di equivalenza per l'analisi energetica in agricoltura. Riv. Ing. Agr. 2:102-114.

Monti A., Venturi G., 2003. Comparison of the energy performance of fibre sorghum, sweet sorghum and wheat monocoltures in northern Italy. Eur. J. Agron. 19:35-43.

Onofrii M., Tomasoni C., Borrelli L., 1993. Confronto tra ordinamenti cerealicolo-foraggeri, sottoposti a due livelli di input agrotecnico, nella pianura irrigua lombarda. I. Produzioni quanti-qualitative. Riv. Agron. 27:60-172.

Onofrii M., Tomasoni C., Borrelli L., 1996. Effects of cereal and forage cropping systems on soil fertility. pp 807-810 in Proc. 16th Meet. EGF. ERSA, Gorizia, Italy.

Parente G., 1996. Grassland and land use systems. pp 23-34 in Proc. 16th Meet. EGF. ERSA, Gorizia, Italy.

Pellizzi G., 1992. Use of Energy and Labour in Italian Agiculture. J. Agr. Eng. Res. 52:111-119.

Pimentel D., 1980. Handbook of energy utilization in agriculture. CRC Press, Boca Raton, FL, USA.

Pimentel D., 1993. Economics and energetics of organic and conventional farming, J. Agr. Environ. Ethic. 6:53-59.

Postma-Blaauw M.B., de Goede R.G.M., Bloem J., Faber J.H., Brussaard L., 2010. Soil biota community structure and abundance under agricultural intensification and extensification. Ecology 91:460-473.

Rathke G.W., Diepenbrock W., 2006. Energy balance of winter oilseed rapeseed (Brassica napus L.) cropping as related to nitrogen supply and preceding crop. Eur. J. Agron. 24:35-44.

Rathke G.W., Wienhold B.J., Wilhelm W.W., Diepenbrock W., 2007. Tillage and rotation effect on corn-soybean energy balances in eastern Nebraska. Soil Till. Res. 97:60-70.

Sharma P., Abrol V., Sharma R.K., 2011. Impact of tillage and mulch management on economics, energy requirement and crop performance in maize-wheat rotation in rainfed subhumid inceptisols, India. Eur. J. Agron. 34:46-51.

Smith P., Olesen J.E., 2010. Synergies between the mitigation of, and adaptation to, climate change in agriculture. J. Agr. Sci. 148:543-552.

Wiens M.J., Entz M.H., Wilson C., Ominski K.H., 2008. Energy requirements for transport and surface application of liquid pig manure in Manitoba, Canada. Agr.Syst. 98:74-81. 